\title{
PENGARUH TERAPI KOGNITIF TERHADAP PENINGKATAN HARGA DIRI REMAJA
}

\author{
Zulian Effendi ${ }^{1}$, Sri Poeranto ${ }^{2}$, Lilik Supriati ${ }^{3}$ \\ ${ }^{1}$ Program Studi Magister Keperawatan Peminatan Jiwa Fakultas Kedokteran Universitas Brawijaya \\ 2,3 Fakultas Kedokteran Universitas Brawijaya \\ Jalan Veteran Malang 65145 \\ Email: effendizulian7@gmail.com
}

\begin{abstract}
Adolescent life in Detention Center is punishment form for the consequences of unlawful behavior ever conducted. The living experience in detention center for adolescent, including life changed, loss of freedom and rights becomes more limited, moreover the acquisition of the label "criminal" attached to him. Those can lead to adolescent experiencing low self esteem in adolescenct where it could lead teen to gets depression and personalitas disorder. Therefore, treatment is required to improve self-esteem in adolescents. This study examines cognitive therapy effect to improving the self-esteem of teenagers in Detention Center. This study design was Quasi Experimental Pre-Post Test With Control Group. Total sample of 28 respondents consist of 14 treatment group and 14 control group were chosen using purposive sampling. The instrument for measuring self-esteem is amodification questionnaire of Roserberg Self-Esteem Scale. These results indicate there is a difference between the increase in adolescent self-esteem before and after HDR generalist therapy and cognitive therapy in the treatment group ( $p$-value $=0.000)$. In the control group there were differences in the increase in self-esteem between before and after therapy is given generalist HDR $(p$-value $=0.000)$, while for adolescent self-esteem after a given intervention between treatment groups with the control group there were differences improved self-esteem among the treatment group and control group after a given intervention ( $p$-value $=0.006$ ). Generalist therapy and cognitive therapy have more meaningful impact on adolescent self-esteem compared to given only by therapy generalist.
\end{abstract}

Keywords: self-esteem, cognitive therapy, adolescent

Abstrak: Kehidupan remaja di Lembaga Pembinaan Khusus Anak (LPKA) merupakan bentuk dari konsekuensi hukuman atas perilaku melanggar hukum yang pernah dilakukan. Berbagai permasalahan dialami remaja dalam menjalani kehidupannya di LPKA, diantaranya perubahan hidup, hilangnya kebebasan dan hak-hak yang semakin terbatas, hingga perolehan label "panjahat" yang melekat pada dirinya.Oleh sebab itu, dibutuhkan terapi untuk meningkatkan harga diri pada remaja. Penelitian ini bertujuan melihat pengaruh terapi kognitif terhadap peningkatan harga diri remaja di LPKA. Penelitian ini menggunakan desain Quasi Experimental Pre-Post Test with Control Group. Jumlah sampel sebanyak 28 responden yang terdiri dari 14 kelompok perlakuan dan 14 kelompok kontrol dengan teknik purposive sampling. Instrument pengukuran harga diri menggunakan kuesioner yang di modifikasi dari Roserberg Self-Esteem Scale. Hasil penelitian ini menunjukkan terdapat perbedaan peningkatan harga diri remaja antara sebelum dan sesudah diberikan terapi generalis HDR dan terapi kognitif pada kelompok perlakuan (nilai $p$-value $=0,000$ ). Pada kelompok kontrol terdapat perbedaan peningkatan harga diri antara sebelum dan sesudah diberikan terapi generalis HDR (nilai $p$-value $=0,000$ ), sedangkan untuk harga diri remaja sesudah diberikan intervensi antara kelompok perlakuan dengan kelompok kontrol terdapat perbedaan peningkatan harga diri antara kelompok perlakuan dengan kelompok kontrol setelah diberikan intervensi (nilai p-value $=0,006$ ). Pemberian terapi generalis dan terapi kognitif memiliki pengaruh yang lebih bermakna terhadap peningkatan harga diri remaja dibandingkan dengan pemberian tindakan generalis saja.

Kata kunci: harga diri, terapi kognitif, remaja

\section{PENDAHULUAN}

Remaja merupakan periode perkembangan selama individu mengalami perubahan dari masa kanak-kanak menuju dewasa, biasanya antara usia 13 sampai
20 tahun (Potter \& Perry, 2010). Data demografi penduduk di dunia menunjukkan jumlah populasi remaja merupakan populasi yang paling besar dari penduduk 
dunia. WHO (2009) menyebutkan bahwa $18 \%$ dari penduduk dunia adalah remaja atau sebanyak 1,2 miliar jiwa. Berdasarkan hasil sensus penduduk tahun 2010 , jumlah remaja di Indonesia sekitar 67 juta atau $29 \%$ dari total seluruh populasi (BPS, 2013). Di wilayah Sumatera Selatan pada tahun 2014, populasi remaja berjumlah $27.52 \%$ atau 1.522.196 jiwa (BPS Sumsel, 2014). Banyaknya populasi remaja akan menimbulkan dampak yang buruk jika remaja tersebut menunjukkan perilaku yang negatif dan terlibat kenakalan remaja (BKKBN, 2012).

Tingkat kenakalan remaja di wilayah Indonesia semakin meningkat. Data Markas Besar Polisi Republik Indonesia menunjukkan bahwa selama tahun 2007 sebanyak 3.145 remaja berusia 18 tahun terlibat tindak kriminal. Pada tahun 2008 sebanyak 3.280 remaja dan tahun 2009 sebanyak 4.213 remaja (BPS, 2010). Kenakalan remaja yang dulu hanya perkelahian dan tawuran antar pelajar kini telah mengarah pada tindakan kriminal seperti perampasan, pemerkosaan, penggunaan narkoba dan pembunuhan (BPS, 2010). Kenakalan remaja berupa tindak kriminal dapat membawa remaja berhadapan dengan hukum. Hal ini membuat remaja divonis bersalah yang kemudian menyebabkan remaja menjalani masa-masa berada di Lapas sebagai narapidana.

Whitehead dan Steptoe (2007) berpendapat bahwa pengalaman hidup di Lapas merupakan bagian pengalaman kehidupan yang paling penuh dengan tekanan, hal tersebut dikarenakan keadaan yang jauh dari orang tua dan keluarga serta penyesalan yang menimbulkan penilaian negatif terhadap diri sendiri, merasa tidak berharga dibandingkan dengan anak seusianya, mendapat celaan dari orang lain, merasa tidak punya harapan, merasa gagal sehingga pada akhirnya dapat menimbulkan harga diri rendah. Hal ini diperkuat dengan pernyataan Matsuura et al (2010) yang mengatakan bahwa remaja yang melakukan tindakan kriminal paling serius memiliki harga diri rendah yang signifikan dibandingkan dengan populasi umumnya.

Penelitian Armeliza (2013) menggambarkan bahwa jumlah remaja di
Lapas Anak Kelas II B Pekanbaru yang memiliki harga diri positif dan harga diri negatif hampir sama. Persentase Remaja di lapas anak yang memiliki harga diri negatif sedikit lebih besar yaitu sebanyak $55 \%$.Berdasarkan studi pendahuluan yang dilakukan peneliti di Lembaga Pembinaan Khusus Anak (LPKA) Kelas I Palembang, dengan menyebarkan kuesioner kepada 20 orang narapidana remaja, didapatkan hasil sebanyak 16 orang narapidana remaja $(80 \%)$ mengalami harga diri rendah. Harga diri rendah yang terjadi pada narapidana remaja di LPKA akan menghambat penyesuaian diri mereka terhadap lingkungan lapas dan apabila tidak diatasi dapat menyebabkan remaja depresi dan gangguan kejiwaan.

Terapi kognitif adalah salah satu bentuk psikoterapi yang didasarkan pada konsep proses patologi jiwa, dimana fokus dari tindakannya berdasarkan modifikasi dari distorsi kognitif dan perilaku maladapatif (Townsend, 2014). Menurut Nevid, Rathus, dan Greene (2008) terapi kognitif juga berfokus untuk membantu klien mengidentifikasi dan mengkoreksi pikiran maladaptif, jenis pikiran otomatis, dan mengubah perilaku diri yang didominasi oleh dorongan dimensi emosional.

Pemberian terapi kognitif pada remaja di LPKA diharapkan dapat menstimulus remaja untuk memiliki pola pikir yang positif sehingga dapat mengatasi masalah harga diri rendah yang dialami dan meningkatkan kualitas hidupnya. Tujuan dari penelitian ini yaitu mengetahui pengaruh terapi kognitif terhadap peningkatan harga diri remaja di LPKA.

\section{METODE}

Penelitian ini adalah penelitian kuantitatif dengan pendekatan quasi experimental menggunakan desain prepost test with control group" dengan intervensi tindakan keperawatan generalis dan terapi kognitif. Kelompok kontrol hanya mendapat intervensi berupa tindakan keperawatan generalis saja. Sedangkan kelompok perlakuan yang didapat adalah tindakan keperawatan generalis dan terapi kognitif sebanyak empat sesi. Teknik pengambilan sampel secara purposive 
sampling. Masing-masing kelompok berjumlah 14 responden.

Kuesioner yang digunakan pada penelitian ini menggunakan kuesioner yang dimodifikasi dari Rosenborg Scale's berjumlah 15 pertanyaan. Responden diseleksi dengan menggunakan kuesioner tersebut dan bila memiliki nilai total $\leq 23$ maka individu memenuhi kriteria untuk menjadi responden. Kriteria yang lain adalah klien berusia 13-18 tahun, merupakan tahanan dan narapidana, dapat membaca dan menulis, kooperatif, mampu berkomunikasi dengan baik dan bersedia menjadi responden. Analisis statistik yang dipergunakan yaitu univariat dan bivariat dengan analisis paired t-test dan independent-sample t-test dengan tampilan dalam bentuk tabel dan distribusi frekuensi.

\section{HASIL PENELITIAN}

\section{Karakteristik Responden}

Tabel 1. Karakteristik Responden

Remaja Di Lembaga Pembinaan Khusus Anak Tahun 2016.

\begin{tabular}{llccc}
\hline Variabel & Kelompok & $\mathbf{n}$ & Med & $\begin{array}{c}\text { Min- } \\
\text { Maks }\end{array}$ \\
\hline Usia & $\begin{array}{l}\text { Perlakuan } \\
\text { Kontrol }\end{array}$ & 14 & 16 & $14-18$ \\
& \multicolumn{4}{c}{ Sumber: Data Primer 2016 }
\end{tabular}

Berdasarkan tabel 1 diketahui bahwa usia pada kelompok perlakuan usia paling muda yaitu 14 tahun dan usia paling tua yaitu 18 tahun dengan nilai median 16 . Pada kelompok kontrol usia paling muda yaitu 15 tahun dan usia paling tua yaitu 18 tahun dengan nilai median 17.

Berdasarkan tabel 2 diketahui bahwa usiatingkat pendidikan pada kelompok perlakuan dan kelompok kontrol memiliki proporsi yang hampir sama. Pada kedua kelompok paling banyak memiliki tingkat pendidikan SMP yaitu sebanyak 7 responden $(50 \%)$ pada kelompok perlakuan dan 9 responden (64\%) pada kelompok kontrol.

Tabel 2. Karakteristik Responden Remaja Di Lembaga Pembinaan Khusus Anak Tahun 2016

\begin{tabular}{llcccc}
\hline Variabel & Kategori & \multicolumn{2}{c}{$\begin{array}{c}\text { Kelompok } \\
\text { Kontrol }\end{array}$} & \multicolumn{2}{c}{$\begin{array}{c}\text { Kelompok } \\
\text { Perlakuan } \\
(\mathrm{N}=14)\end{array}$} \\
\cline { 3 - 6 } & & $\mathrm{N}=14)$ \\
\hline Pendidikan & SD & 5 & 36 & 4 & $\%$ \\
& SMP & 7 & 50 & 9 & 64 \\
& SMA & 2 & 14 & 1 & 7 \\
& Total & 14 & 100 & 14 & 100 \\
\hline Status & Tinggi & 1 & 7 & 2 & 14 \\
Ekonomi & Rendah & 13 & 93 & 12 & 86 \\
& Total & 14 & 100 & 14 & 100 \\
& & & & & \\
\hline Kunjungan & Sering & 2 & 14 & 1 & 7 \\
Keluarga & Jarang & 8 & 57 & 8 & 57 \\
& Tidak & 4 & 29 & 5 & 36 \\
& Pernah & 14 & 100 & 14 & 100 \\
& Total & & & & \\
& & & & & \\
& & & & &
\end{tabular}

Sumber: Data Primer 2016

Status ekonomi pada kelompok perlakuan sebagian besar responden mempunyai status ekonomi rendah yaitu sebanyak 13 remaja (93\%). Pada kelompok kontrol sebagian besar responden mempunyai status ekonomi rendah sebanyak 12 remaja (86\%). Pada variabel kunjungan keluarga pada kelompok intervensi dan kelompok kontrol memiliki proporsi kunjungan keluarga yang jarang dengan persentase yang sama yaitu $57 \%$ (8 responden).

\section{Harga Diri Remaja di Lembaga Pembinaan Khusus Anak}

Tabel 3. Distribusi harga diri sebelum dan sesudah intervensi pada kelompok perlakuan dan kelompok kontrol pada remaja

\begin{tabular}{llccccc}
\hline Kelompok & Intervensi & $\mathbf{n}$ & Mean & SD & Min-Max & $\mathbf{9 5 \%} \mathbf{C l}$ \\
\hline Perlakuan & Sebelum & 14 & 20,1 & 2,5 & $16-23$ & $18,7-21,6$ \\
& Sesudah & 14 & 28 & 3,7 & $24-34$ & $25,9-30,1$ \\
\hline \multirow{2}{*}{ Kontrol } & Sebelum & 14 & 20,6 & 1,9 & $16-23$ & $19,5-21,7$ \\
& Sesudah & 14 & 24,2 & 2,9 & $20-29$ & $22,5-25,9$ \\
\hline
\end{tabular}


Berdasarkan tabel 3 di atas dapat diketahui rata-rata skor harga diri remaja sebelum intervensi pada kelompok perlakuan sebesar 20,1 dengan skor terendah 16 dan skor tertinggi $23(95 \% \mathrm{Cl}$ remaja yang mengalami harga diri rendah sebelum diberikan terapi kognitif pada kelompok perlakuan berada pada rentang 18,7-21,6). Rata-rata skor harga diri remaja sesudah intervensi pada kelompok perlakuan meningkat sebesar 28 (standar deviasi 3,7) di mana skor tersebut menunjukkan bahwa harga diri remaja mengalami peningkatan dengan skor terendah 24 dan skor tertinggi 34 .
Rata-rata skor harga diri remaja pada kelompok kontrol sebelum intervensi sebesar 20,6 dengan skor terendah 16 dan skor tertinggi $23(95 \% \mathrm{Cl}$ remaja pada kelompok kontrol yang mengalami harga diri rendah berada pada rentang 19,521,7). Rata-rata skor harga diri remaja pada kelompok kontrol setelah intervensi menjadi 24,2 (standar deviasi 2,9) dimana skor tersebut menunjukkan adanya peningkatan harga diri remaja dengan skor terendah 20 dan skor tertinggi 29.

\section{Perbedaan Harga Diri Remaja Sebelum dan Sesudah diberikan Terapi Generalis dan Terapi Kognitif Pada Kelompok Perlakuan}

Tabel 4. Hasil uji t berpasangan perbedaan harga diri remaja sebelum dan sesudah intervensi pada kelompok perlakuan

\begin{tabular}{ccccccc}
\hline \multicolumn{1}{c}{ Harga Diri } & $\mathrm{n}$ & Mean & Mean Difference & $95 \% \mathrm{Cl}$ & $\mathrm{t}$ & $\mathrm{p}$-value \\
\hline Sebelum & 14 & 20,1 & $-7,86$ & $-9,1 \mathrm{~s} / \mathrm{d}-6,6$ & $-13,5$ & 0,000 \\
Sesudah & 14 & 28 & & & & \\
\hline
\end{tabular}

Berdasarkan tabel 4 diketahui bahwa nilai signifikansi 0,000 ( $p$ value $<0,05$ ) dengan selisih $-7,86(95 \% \mathrm{Cl}-9,1$ sampai dengan $-6,6)$ serta nilai t hitung $-13,5$ yang menunjukkan lebih kecil dari $t$ tabel ($2,160)$. Karena nilai $p$ value $<0,05$ dan interval kepercayaan tidak melewati nol serta nilai $\mathrm{t}$ hitung $<\mathrm{t}$ tabel, maka Ho ditolak. Hal ini menunjukkan secara statistik terdapat perbedaan yang bermakna pada harga diri remaja pada kelompok perlakuan sebelum dan sesudah diberikan terapi kognitif dan terapi generalis HDR.

\section{Perbedaan Harga Diri Remaja Sebelum dan Sesudah diberikan Terapi Generalis Pada Kelompok Kontrol}

Tabel 5. Hasil Uji t berpasangan perbedaan Harga Diri Remaja Sebelum dan Sesudah Intervensi Pada Kelompok Kontrol

\begin{tabular}{lcccccc}
\hline Harga Diri & $\mathrm{n}$ & Mean & Mean Difference & $95 \% \mathrm{Cl}$ & $\mathrm{t}$ & $\mathrm{p}$-value \\
\hline Sebelum & 14 & 20,57 & $-3,64$ & $-4,8 \mathrm{~s} / \mathrm{d}-2,5$ & $-6,7$ & 0,000 \\
Sesudah & 14 & 24,21 & & & & \\
\hline
\end{tabular}

Sumber: Data Primer 2016

Berdasarkan tabel 5 diketahui bahwa nilai signifikansi 0,000 ( $p$ value $<0,05$ ) dengan selisih $-3,64$ (95\% Cl -4,8 sampai dengan $-2,5)$ serta nilai t hitung $-6,7$ yang menunjukkan lebih kecil dari $t$ tabel (-
$2,160)$. Karena nilai $p$ value $<0,05$ dan interval kepercayaan tidak melewati nol serta nilai $t$ hitung $<\mathrm{t}$ tabel, maka Ho ditolak. Hal ini menunjukkan secara statistik terdapat perbedaan yang 
bermakna pada harga diri remaja pada

diberikan terapi generalis HDR.

kelompok kontrol sebelum dan sesudah

\section{Perbedaan Harga Diri Remaja Antara Kelompok Perlakuan dan Kelompok Kontrol Sesudah diberikan Intervensi}

Tabel 6. Hasil uji t tidak berpasangan perbedaan harga diri remaja sesudah intervensi antara kelompok kontrol dan perlakuan

\begin{tabular}{lcccccc}
\hline \multicolumn{1}{c}{ Harga Diri } & $\mathrm{n}$ & Mean & Mean Difference & $95 \% \mathrm{Cl}$ & $\mathrm{t}$ & $\mathrm{p}$-value \\
\hline Kontrol & 14 & 24,2 & $-3,79$ & $-6,4 \mathrm{~s} / \mathrm{d}-1,2$ & $-3,01$ & 0,006 \\
Perlakuan & 14 & 28 & & & & \\
\hline
\end{tabular}

Sumber: Data Primer 2016

Berdasarkan tabel 6 diketahui bahwa nilai p 0,006 ( $p$ value $<0,05$ ) dengan selisih $3,79(95 \% \mathrm{Cl}-6,4$ sampai dengan -1,2) serta nilai $t$ hitung - 3,01 yang menunjukkan lebih kecil dari $t$ tabel ($2,160)$. Karena nilai $p$ value $<0,05$ dan interval kepercayaan tidak melewati nol serta nilai t hitung < t tabel secara statistik terdapat perbedaan yang bermakna skor harga diri remaja antara kelompok kontrol dan kelompok perlakuan sesudah diberikan intervensi.

\section{PEMBAHASAN}

\section{A. Perbedaan harga diri remaja sebelum dan sesudah diberikan terapi generalis dan kognitif pada kelompok perlakuan}

Hasil penelitian yang telah dilakukan menunjukkan harga diri pada kelompok perlakuan sesudah mendapatkan terapi generalis dan terapi kognitif rata-rata meningkat sebesar 7,86 . Hasil penelitian diketahui seluruh responden mengalami peningkatan pada skor harga diri yang ditunjukkan secara bermakna berdasarkan uji statistik dengan menggunakan uji $t$ berpasangan didapatkan nilai $\mathrm{p}$ value $=$ 0,000 ( $p$ value $<0,05$ ). Sehingga dapat disimpulkan bahwa dengan pemberian terapi kognitif kepada remaja berpengaruh secara bermakna terhadap peningkatan harga diri remaja.

Hasil penelitian ini selaras dengan penelitian yang dilakukan oleh Ingul et al. (2013) yang membuktikan bahwa dengan pemberian terapi kognitif memberikan efek lebih besar dalam mengurangi gejala serta memperbaiki kondisi remaja yang mengalami fobia sosial yang berpengaruh terhadap harga diri remaja tersebut.

Terapi kognitif merupakan salah satu bentuk psikoterapi yang melatih klien untuk mengubah pikiran otomatis negatif dan cara pandang seseorang terhadap sesuatu sehingga menimbulkan perasaan lebih baik dan dapat bertindak lebih produktif (Varcarolis, 2013). Penelitian yang dilakukan oleh Matsuura et al. (2010) menemukan bahwa remaja yang melakukan tindakan kriminal paling serius memiliki harga diri rendah yang signifikan dibandingkan dengan populasi umumnya.

Remaja yang berada di lembaga pembinaan khusus anak dengan harga diri rendah mengalami pikiran otomatis negatif yaitu kesalahan cara berpikir tentang diri sendiri, lingkungan danmasa depan, serta muncul pikiran-pikiran negatif selama berada di tahanan. Hal ini selaras dengan pernyataan Power (2010) yang menyatakan remaja yang mengalami harga diri rendah akan menerjemahkan pikiran otomatis negatif dimulai dari memikirkan apa yang telah terjadi sehingga menimbulkan asumsi, ketika asumsi tersebut terus berulang maka akan mengaktifkan asumsi buruk yang akan menghasilkan pikiran otomatis negatif dan akhirnya diterjemahkan melalui perasaan, pikiran dan perilaku baik secara intrapersonal ataupun interpersonal.

Pada saat sesi terapi teridentifikasi pikiran otomatis negatif yang timbul dari responden perlakuan di LPKA antara lain merasa dirinya gagal, merasa tidak berguna, merasa tidak memiliki masa depan lagi, merasa dirinya bodoh, merasa tidak bisa membanggakan orang tua, merasa takut tidak diterima lingkungan 
sekitar ketika keluar dari penjara. Pikiran otomatis negatif yang dihasilkan remaja di LPKA ini menghasilkan perilaku maladaptif yang mengarah kepada harga diri rendah sehingga remaja sering menghindar terhadap lingkungan sekitar. Hal ini selaras dengan studi yang dilakukan Waite et al (2012) yang menyatakan bahwa remaja dengan harga diri rendah akan merasa tidak nyaman di suatu lingkungan sehingga dia cenderung akan menghindar dan dan jika terus menerus dilakukan akan mempengaruhi harga dirinya.

Tingginya harga diri diasosiasikan dengan pembentukan strategi koping yang baik, tingginya motivasi, serta emosi secara positif (Harter, 2006). Pemberian terapi kognitif mampu merubah pikiranpikiran negatif pada remaja dengan harga diri rendah menjadi pikiran yang lebih positif serta remaja yang memiliki perilaku maladaptif menjadi efektif sesuai dengan kemampuan yang dimiliki sehingga kualitas hidup yang baik akan tercapai.

Hasil penelitian ini sejalan dengan penelitian yang dilakukan Rahayuningsih (2007) dalam penelitiannya yang berjudul pengaruh terapi kognitif terhadap tingkat harga diri dan kemandirian pasien dengan kanker payudara didapatkan hasil bahwa dari 29 responden, $100 \%$ responden mengalami harga diri rendah sebelum dilakukan terapi kognitif dan setelah dilakukan terapi kognitif terjadi peningkatan harga diri menjadi harga diri tinggi pada 17 responden $(58,6 \%)$. Hal ini menunjukkan bahwa terapi kognitif bermanfaat pada pasien dengan gangguan kesehatan fisik yang mengalami harga diri rendah. Hasil yang sama juga didapatkan oleh Kristiyaningsih (2009) yang meneliti tentang pengaruh terapi kognitif terhadap perubahan harga diri rendah dan kondisi depresi pasien gagal ginjal kronik didapatkan kesimpulan bahwa terdapat perubahan bermakna terhadap rata-rata tingkat harga diri dan kondisi pasien.

Terapi kognitif sendiri diyakini dapat meningkatkan harga diri remaja. Hal ini sesuai dengan tujuan terapi kognitif yaitu untuk mengubah pikiran negatif menjadi positif, mengetahui penyebab perasaan negatif yang dirasakan, membantu mengendalikan diri. Menurut Copel (2007) terapi kognitif bertujuan untuk membantu pasien mengembangkan pola pikir yang rasional dan membentuk kembali perilaku dengan mengubah pesan-pesan internal. Terapi kognitif berfokus pada bagaimana cara mengidentifikasi dan memperbaiki persepsi-persepsi pasien yang bias yang terdapat dalam pikirannya (Frisch \& Frisch, 2006).

Berdasarkan uraian hasil penelitian tersebut diatas, maka dapat disimpulkan bahwa dengan pemberian terapi kognitif kepada remaja di lembaga pembinaan khusus anak berpengaruh secara bermakna terhadap peningkatan harga diri remaja. Hal ini membuktikan bahwa tingkat harga diri dapat dipengaruhi oleh pemberian intervensi keperawatan spesialistik yang adekuat salah satunya dengan pemberian terapi kognitif.

\section{B. Perbedaan harga diri remaja sebelum dan sesudah diberikan terapi generalis pada kelompok kontrol}

Hasil analisis statistik pada kelompok kontrol terhadap harga diri remaja menunjukkan bahwa terdapat perubahan pada harga diri remaja sebelum dan sesudah diberikan terapi generalis HDR dengan rata-rata responden mengalami peningkatan harga diri sebesar 3,64. Hal ini ditunjukkan secara bermakna berdasarkan uji statistik dengan menggunakan uji $t$ berpasangan didapatkan nilai $p$ value $=0,000$ ( $p$ value $<$ $0,05)$. Sehingga dapat disimpulkan bahwa dengan pemberian terapi generalis HDR kepada remaja berpengaruh secara bermakna terhadap peningkatan harga diri remaja.

Intervensi penelitian yang diberikan untuk remaja pada kelompok kontrol adalah terapi generalis harga diri rendah di mana terapi ini bertujuan untuk meningkatkan psikomotor atau kemampuan responden dalam mengatasi masalah keperawatan yang dialaminya (Keliat dkk, 2011). Proses pelaksanaan terapi generalis ini dimulai dengan terapis dan responden mendiskusikan sejumlah kemampuan dan aspek positif yang dimiliki pasien seperti kegiatan pembinaan yang ada di lembaga pembinaan khusus anak kelas I Palembang. Selanjutnya terapis mendorong penggunaan aspek positif dan 
kemampuan yang dimiliki klien serta mengevaluasi semua proses pelaksanaan terapi.

Hal yang mendukung berhasilnya tindakan keperawatan generalis pada remaja di lembaga pembinaan khusus anak menurut peneliti adalah dikarenakan remaja dapat mempraktekkan bersama dengan bimbingan terapis. Selain itu remaja berpartisipasi aktif dalam setiap pertemuan dalam pelaksanaan tindakan keperawatan generalis. Tindakan ini ternyata memberikan efek menaikkan tingkat harga diri remaja di lembaga pembinaan khusus anak berdasarkan hasil penelitian walaupun tidak sebesar apabila ditambah dengan terapi kognitif.

Temuan ini selaras dengan penelitian yang dilakukan Rochdiat (2016) tentang pengaruh tindakan keperawatan generalis dan terapi suportif terhadap perubahan harga diri klien diabetes melitus di RS panembahan senopati Bantul didapatkan bahwa tindakan keperawatan generalis memberikan efek menaikkan tingkat harga diri klien DM.

Pada penelitian ini didapatkan sebanyak 4 responden pada kelompok kontrol setelah dilakukan intervensi terapi generalis tetap mengalami harga diri rendah tetapi pada skor harga dirinya mengalami peningkatan dan 2 responden tidak mengalami perubahan pada skor harga diri. Apabila dilihat dari karakteristik responden dapat disebabkan karena usia responden ini adalah remaja awal (13-16 tahun). Pada kelompok usia tersebut merupakan masa pembentukan harga diri yang cenderung tidak stabil. Hal ini didukung oleh pernyataan Stuart (2014) yang menyatakan bahwa pembentukan harga diri meningkat sesuai dengan usia remaja dan akan terus berkembang sampai remaja akhir serta cenderung stabil ketika dewasa.

Karakteristik responden lainnya adalah dukungan keluarga berupa kunjungan keluarga ke lembaga pembinaan khusus anak. Berdasarkan table 2 diketahui bahwa pada kelompok intervensi dan kelompok kontrol memiliki proporsi kunjungan keluarga yang jarang dengan persentase yang sama yaitu $57 \%$. Dapat diasumsikan bahwa remaja yang mengalami harga diri rendah pada penelitian ini memiliki dukungan keluarga yang kurang hal tersebut dapat dilihat dari kunjungan keluarga ke lembaga pembinaan khusus anak yang jarang.

Hal ini sesuai dengan penelitian yang dilakukan oleh Ikiz et al. (2010) dalam penelitiannya menunjukkan bahwa remaja yang memiliki dukungan orang tua mempunyai harga diri yang tinggi saat mereka menghadapi masalah atau kegagalan sedangkan remaja yang tidak memiliki dukungan orang tua mempunyai harga diri yang rendah saat mereka menghadapi masalah atau mengalami kegagalan.

Meskipun skor akhir pada responden belum semuanya meningkat dan mencapai kategori harga diri tinggi tetapi sudah menunjukkan hasil yang cukup bermakna dalam meningkatkan harga diri remaja di lembaga pembinaan khusus anak kelas I Palembang. Dapat peneliti asumsikan bahwa harga diri akan dapat terus meningkat jika terapi generalis yang telah diajarkan kepada remaja yang mengalami harga diri rendah, dapat dilakukan terus menerus oleh remaja secara mandiri.

\section{Perbedaan harga diri remaja sesudah diberikan intervensipada kelompok perlakuan dan kelompok kontrol}

Hasil uji statistik dengan menggunakan uji t tidak berpasangan pada tabel 6 menunjukkan bahwa terdapat perbedaan yang signifikan pada harga diri remaja antara kelompok perlakuan dan kelompok kontrol dengan nilai $\mathrm{p}$ value $=$ 0,006 ( $p$ value $<0,05$ ). Sehingga dapat disimpulkan bahwa peningkatan harga diri pada kelompok intervensi sesudah pemberian terapi kognitif berbeda secara signifikan dengan kelompok kontrol yang hanya diberikan terapi generalis HDR.

Hasil penelitian ini menunjukkan bahwa kedua kelompok mempunyai peningkatan yang bermakna. Akan tetapi juga memiliki selisih perbedaan yang bermakna yaitu pada kelompok perlakuan yang mendapat tambahan terapi kognitif mengalami peningkatan harga diri yang lebih tinggi dibandingkan dengan kelompok kontrol yang hanya diberikan tindakan generalis harga diri rendah. Hal ini dikarenakan bahwa tindakan generalis 
dalam pelaksanaannya hanya mendiskusikan mengidentifikasi serta mendorong kemampuan dan aspek positif yang dimiliki oleh klien dengan metode diskusi. Sedangkan terapi kognitif merubah pola pikir yang awalnya memiliki pikiran otomatis negatif menjadi pikiran yang positif sehingga dapat merubah perilaku yang maladaptif. Hal ini sesuai dengan penelitian Pasaribu (2012) yang menyatakan bahwa terapi kognitif dan terapi penghentian pikiran secara bermakna dapat meningkatkan kemampuan mengontrol pikiran negatif pasien kanker.

Terapi kognitif merupakan terapi yang didasarkan pada kesalahan berfikir klien dengan muncul pikiran otomatis negatif yang mendorong pada penilaian negatif terhadap diri sendiri dan orang lain (Varcarolis, 2013). Terapi kognitif berfokus pada pemrosesan pikiran dengan segera yaitu bagaimana individu mempersepsikan atau menginterpretasi pengalamannya dan menentukan bagaimana cara dia merasakan dan berperilaku.

Pada sesi akhir, terapis berdiskusi tentang manfaat berpikir positif dan bagaimana manfaat latihan selama ini sehingga diharapkan responden akan menyadari pentingnya mengontrol pikiran negatif dan dilakukan terus jika pikiran otomatis negatif muncul serta mengajak teman terdekat klien untuk menjadi support system dalam upaya peningkatan harga diri pada remaja di lembaga pembinaan khusus anak. Hal ini selaras dengan penelitian yang dilakukan oleh Chatterton et al. (2007) tentang terapi kognitif pada harga diri seorang wanita yang berpikir untuk bunuh diri, skor akhir memperlihatkan peningkatan yang signifikan harga diri setelah diberikan terapi kognitif. Dalam penelitiannya Chatterton berkesimpulan bahwa terapi kognitif ini memakai pendekatan pada atribut positif dari klien yang berfokus pada masalah dan pikiran otomatis negatifnya.

Pada penelitian ini juga, pemberian terapi diberikan secara individu sehingga responden dapat leluasa mengeksplorasi perasaan dan pikiran yang dimiliki selama ini terkait harga dirinya. Hal ini didukung dengan penelitian yang dilakukan Ingul (2013) dan Mortberg (2007) yang menyatakan bahwa terapi yang dilaksanakan secara individu lebih efektif daripada berkelompok. Hal ini terjadi karena lebih terjaga secara privasi. Terapi dilakukan di ruang tertutup sehingga di ruangan hanya ada terapis dan satu responden saja setiap kali dilakukan terapi.

Hasil penelitian ini membuktikan bahwa adanya peningkatan skor harga diri pada kelompok intervensi secara bermakna dibandingkan dengan pada kelompok kontrol di mana pada kelompok intervensi didapat selisih peningkatan harga diri yang bermakna, yang berarti harga diri pada remaja pada kelompok intervensi dapat meningkat setelah diberikan terapi generalis dan terapi kognitif. Hal ini mendukung teori yang dikemukakan oleh Townsend (2014) yang menerangkan bahwa proses pelaksanaan terapi kognitif merupakan suatu terapi yang berorientasi pada tujuan penyelesaian masalah pasien. Di awal pertemuan, terapis harus mengidentifikasi masalahmasalah yang dihadapi pasiennya. Kemudian bersama-sama menetapkan tujuan dan hasil yang diharapkan dalam terapi. Proses diskusi dalam menyelesaikan permasalahan yang dihadapi pasien dibutuhkan saat pasien mulai dapat mengenal distorsi kognitif dan memperbaiki pola pikirnya.

Hasil penelitian ini sejalan dengan hasil penelitian yang dilakukan oleh Suerni dkk. (2013) yang meneliti tentang Penerapan Terapi Kognitif Dan Psikoedukasi Keluarga Pada Klien Harga Diri Rendah didapatkan hasil penerapan pada 15 klien dengan tindakan keperawatan generalis dan terapi kognitif menunjukkan penurunan tanda dan gejala harga diri rata-rata 54,94\%; peningkatan kemampuan rata-rata 89,57\%. Berdasarkan penurunan tanda dan gejala, peningkatan kemampuan klien maka terapi kognitif direkomendasikan pada klien dengan harga diri rendah.

Penelitian lain yang dilakukan oleh Farahmand et al (2013) menemukan bahwa terjadi peningkatan harga diri yang signifikan pada pasien depresif dibandingkan dengan kelompok kontrol setelah diintervensi dengan terapi kognitif di Iran. Temuan lainnya pada remaja perempuan yang memiliki masalah berat 
badan obesitas di Prancis, terapi kognitif dinilai efektif untuk meningkatkan harga diri remaja perempuan tersebut (Fossati, 2004).

Kesimpulan akhir dari hasil penelitian terhadap tingkat harga diri remaja di lembaga pembinaan khusus anak adalah bahwa ada peningkatan yang bermakna dalam selisih tingkat harga diri antara kelompok intervensi dengan kelompok kontrol setelah pelaksanaan intervensi terapi kognitif ( $p$ value $<0,05$ ). Kesimpulan lainnya adalah dengan pemberian intervensi keperawatan spesialistik dapat memberikan hasil yang lebih baik bila dibandingkan hanya mendapatkan intervensi keperawatan dasar (generalis).

\section{KESIMPULAN}

Pemberian terapi generalis HDR dan terapi kognitif memberikan pengaruh yang signifikan terhadap peningkatan harga diri remaja yang ditandai dengan adanya perbedaan harga diri sebelum dan sesudah diberikan terapi generalis HDR dan terapi kognitif pada kelompok perlakuan.

\section{DAFTAR PUSTAKA}

Armeliza, V. (2013). Gambaran konsep diri remaja di lembaga pemasyarakatan. PSIK UNRI: Pekanbaru.

Badan Kependudukan dan Keluarga Berencana Nasional. (2012). Fenomena Kenakalan Remaja di Indonesia.http://ntb.bkkbn.go.id/Lists/ Artikel/

DispForm.aspx?ID=673\&ContentTyp eld=0x01003DCABABC04B7084595 DA364423DE7897. Diakses tanggal 15 Januari 2016

Badan Pusat Statistik. (2010). Profil Kriminalitas Remaja 2010. (Online). http://www.bps.go.id/hasil publikasi/fl ip 2011/4401003/files/search/searcht ext.xml. Diakses tanggal 15 Januari 2016

Copel, L.C. (2007). Kesehatan Jiwa \& Psikiatri, Pedoman Klinis Perawat(Psychiatric and Mental Health Care: Nurse's Clinical Guide). Jakarta: EGC
Pemberian terapi generalis HDR memberikan pengaruh yang signifikan terhadap peningkatan harga diri remaja yang ditandai dengan adanya perbedaan harga diri sebelum dan sesudah diberikan terapi generalis HDR pada kelompok kontrol.

Terdapat perbedaan peningkatan harga diri remaja pada kelompok perlakuan sesudah diberikan terapi generalis HDR dan terapi kognitif dan pada kelompok kontrol sesudah diberikan terapi generalis HDR.

\section{SARAN}

Pelayanan kesehatan jiwa di lembaga pembinaan khusus anak perlu dikembangkan sebagai upaya promotif, preventif dan kuratif untuk dapat meningkatkan kesehatan jiwa di lembaga pembinaan khusus anak dengan mengadakan kerja sama dengan pihak institusi pendidikan tinggi.

Ke depan, perlu dikembangkan penelitian lanjutan sebagai model terapi yang dikolaborasikan dengan terapi kognitif untuk upaya meningkatkan harga diri di lembaga pembinaan khusus anak.

Farahmand V, Hassanzadeh R, Mirzaian B, Fayyazi, Bordbar MR, Feizi J. (2014) The efficacy of group metacognitive therapy on self-esteem and mental health of patients suffering from major depressive disorder. Iran Journal Psychiatry Behavior Sci 2014; 8(2): 4-10.

Fossati, M., rieker,A\& golay. (2004). Therapie cognitive en groupe de l'estime de soi chez de patients obezes . Aftcc, paris .Journal de therapy comportementale et cognitive. 14:1, 29-34.

Frisch, N.C. \& Frisch, L.E. (2006). Psychiatric Mental Health Nursing. (3th ed). New York: Thomson Delmar LearningHarter, S. (2006). The development of self-representations in childhood and adolescence $\left(6^{\text {th }}\right.$ ed.). New York:Wiley

Ikiz, F. E., Cakar, F. S. (2010). Perceived social support and sel-esteem in 
adolescent. Social and Behavior Sciences. $5: 338-342$.

ngul, J.M, Aune, \& Nordahl. (2013). A Randomized Controlled Trial of Individual Cognitive Therapy, Group Cognitive Behaviour Therapy and Attentional Placebo for Adolescent Social Phobia. Psychother Psychosom Journal 2014;83:54-61.

Kaplan, H.I.\& Sadock,B.J. (2010). Sinopsis psikiatri. Edisi Ketujuh. Jakarta: Binarupa Aksara.

Keliat, B. A. (2011). Keperawatan Kesehatan Jiwa Komunitas: $C M H N$ Basic Course. Jakarta: EGC.

Kristyaningsih, F., Keliat, B. A. dan Helena,. N. C. D. (2009): Pengaruh Terapi Kognitif terhadap Perubahan Harga Diri dan Kondisi Depresi Pasien Gagal Ginjal Kronik di Ruang Haemodialisa RSUP Fatmawati Jakarta. Universitas Indonesia.

Matsuura, N., Hashimoto, T., Toichi M. (2010). The characteristics of AD/HD symptoms, self-esteem, and aggression among serious juvenile offenders in Japan. Journal Research in Developmental Disabilities. 31 : 1197-1203.

Mortberg E, Clark DM, Sundin O, Wistedt AA. (2007). Intensive group cognitive treatment and individual cognitive herapy vs. treatment as usual in social phobia: a randomized controlled trial. Acta Psychiatric Scandinavian Journal; 115: 142-154.

Nevid, J. S., Rathus, S. A., Greene, B. (2008). Abnormal Psychology in $A$ Changing Word. $10^{\text {th }}$ edition. New Jersey: Pearson-Prentice Hall.

Pasaribu, J. (2012). Pengaruh terapi kognitif dan terapi penghentian pikiran terhadap perubahan ansietas, depresi, dan kemampuan mengontrol pikiran negative klien kanker di RS kanker Dharmais, Jakarta.
Universitas Indonesia.

Power. (2010). Emotion-Focused Cognitive Therapy. John Wiley: Oxford Malden.

Rahayuningsih, A. (2007). Pengaruh Terapi Kognitif terhadap tingkat harga diridan kemandirian pasien dengan Kanker Payudara RS Kanker Dharmais.Jakarta: FKUI.

Rosenberg, M. (1965). Society and the adolescent self-image. Princeton, NJ: Princeton University Press.

Stuart, G. W. (2013). Principle and practice of psychiatric nursing (10th ed.). Missouri: Mosby.

Suerni., Keliat, B. A. dan Helena,. N. C. D. (2009): Penerapan Terapi Kognitif Dan Psikoedukasi Keluarga Pada Klien Harga Diri Rendah Di Ruang Yudistira Rumah Sakit Dr. H. Marzoeki Mahdi Bogor. Universitas Indonesia.

Townsend, M.C. (2014). Essentials Of Psychiatric Mental Health Nursing. Concepts Of Care In Evidence-Based Practice. Sixth edition. F.A. Davis Company: Philadelphia.

Varcarolis, E.M. (2013). Essentials of Psychiatric Mental Health Nursing: A Communication Approach do Evidence-Based Care. (2nd ed). St. Louis: Saunders Elsevier.

Waite, McManus, Shafran. (2012). Cognitive therapy for low selfesteem: a preliminary randomized controlled trial in a primary care setting.Journal of Behavior Therapy and Experimental Psychiatry. 43(4):1049-1057. doi: 10.1016/j.jbtep.2012.04.006.

Whitehead, D.L \& Steptoe, A. (2007). Prison. In Fink, G (Ed). Encyclopedia of stress. 2nd edition. Volume 3. pp. 217-221. e-book edition.

WHO. (2009). World Health Statistics 2009. Diakses tanggal 15 Januari 201 